\title{
Red cell folate concentrations in patients with Crohn's disease on parenteral nutrition
}

\section{Masaya Tominaga, Mitsuo Iida, Kunihiko Aoyagi, Norio Kohrogi, Toshiyuki Matsui and Masatoshi Fujishima}

Second Department of Internal Medicine, Faculty of Medicine, Kyushi University, Maidashi 3-1-1, Higashi-Ku, Fukuoka 812, Japan.

\begin{abstract}
Summary: To examine changes in the folate concentrations in red cell during relatively long-term total parenteral nutrition (TPN), 10 Japanese patients with Crohn's disease (7 males), the mean Crohn's disease activity index on admission being 211 , were given folic acid in a dose of $400 \mu \mathrm{g} /$ day (AMA-FDA formulation) or $800 \mu \mathrm{g} /$ day for 6-16 weeks (mean 10.5). The red cell folate concentrations were determined before TPN and once every week or 2-4 weeks thereafter. The folate concentrations were very low even after TPN with folic acid of $400 \mu \mathrm{g} / \mathrm{day}$. In those given $800 \mu \mathrm{g}$ of daily folic acid, the folate levels tended to increase, but did not reach the normal range. We propose that folic acid over $800 \mu \mathrm{g} / \mathrm{day}$ or a double dose of AMA-FDA formulation should be prescribed for Crohn's disease treated with long-term TPN.
\end{abstract}

Introduction

There has been no established drug therapy for Crohn's disease. Total parenteral nutrition (TPN) or elemental diet is a common and primary therapy for this disease, aimed at bowel rest. ${ }^{1-5}$ Most patients, however, are in a state of latent hypoalimentation before the therapy, because of extensive intestinal lesions or due to the lack of ingestion of nutrients. Therefore, various vitamin deficiencies, such as folic acid and vitamin D, can frequently occur in such patients. $^{2}$

To establish the dose of vitamins required for TPN, the Food and Drug Administration (FDA) prepared a parenteral vitamin formulation for adults in 1979, based on recommendations of the Nutrition Advisory Group of the American Medical Association. ${ }^{6}$ However, blood concentrations of vitamins have rarely been investigated in patients treated with long-term TPN, using the AMA-FDA formulation. ${ }^{7}$ We examined serial changes in the folate concentrations in red cell during relatively long-term TPN in 10 patients with Crohn's disease. Of these patients, seven were given the dose of folic acid recommended by AMAFDA and the remaining three were treated with a double dose.

Correspondence: Masaya Tominaga, M.D.

Accepted: 1 June 1989
Materials and methods

\section{Patients}

Ten Japanese patients with Crohn's disease ( 7 males) admitted to Kyushu University hospital between October 1984 and October 1987 were studied. The average age of the patients was 30 years (range 18-52). The diagnosis of Crohn's disease was based on X-ray examination, endoscopy, and biopsy. The sites of lesions were evident in both the small and large intestines in 6 patients, only in the small intestine in 3 , and in the large intestine in one. The period of illness ranged from 1 to 8 years (average 3.4 years). The mean Crohn's disease activity index (CDAI) ${ }^{8}$ on admission was 211 (range 93 to 394). All patients had normal renal and liver function.

\section{Intravenous solution}

Each patient was forbidden to take anything by mouth and was given TPN of $1924 \mathrm{Cal} /$ day. The composition of daily TPN during the maintenance period is shown in Table I. Additionally, an intravenous fat emulsion (INTRAFAT, 10\%, 200-500 ml) was administered through a peripheral vein once a week in each case. Two patients received oral salicylazosulphapyridine (SASP, 3 g/day).

The Fellowship of Postgraduate Medicine, 1989 
Table I Composition of average daily TPN intake

\begin{tabular}{lrl}
\hline Substrate & Amount/day \\
\hline Energy & $8042 \mathrm{~kJ}$ \\
Nitrogen & $91 \mathrm{~g}$ \\
Sodium & $120 \mathrm{mmol}$ \\
Potassium & $60 \mathrm{mmol}$ \\
Chloride & $120 \mathrm{mmol}$ \\
Acetate & $50 \mathrm{mmol}$ \\
Sulphate & $10 \mathrm{mmol}$ \\
Calcium & $8.5 \mathrm{mmol}$ \\
Magnesium & $10 \mathrm{mmol}$ \\
Phosphorus & $300 \mathrm{mg}$ \\
Zinc & $67 \mu \mathrm{mol}$ \\
Copper & $5 \mu \mathrm{mol}$ \\
Iron & $35 \mu \mathrm{mmol}$ \\
Iodine & $1 \mu \mathrm{mol}$ \\
& $2200 \mathrm{ml}$ \\
\hline Total volume &
\end{tabular}

\section{Vitamin infusion}

Administration of folic acid was started from the initiation of TPN, in a dose of $400 \mu \mathrm{g} /$ day (a dose of AMA-FDA formulation) in 7 cases (group A) and in a dose of $800 \mu \mathrm{g} /$ day (a double dose of the AMA-FDA formulation) in 3 (group B). Clinical profiles of group $A$ and $B$ were substantially the same. Other vitamins including vitamin B1, B2, B6, B12, C, nicotinic acid, pantothenic acid, biotin, $A, D, E$, were given according to the AMA-FDA formulation. The vitamins in at least $500 \mathrm{ml}$ of an infusion solution, shielded from the light, were administered during the night.

\section{Sampling}

Blood samples were obtained between $13.00 \mathrm{~h}$ and $15.00 \mathrm{~h}$, during which time no vitamins were given, prior to TPN therapy and every week or every $2-4$ weeks during TPN for $6-16$ weeks with average 10.5 weeks. Blood samples were frozen immediately after sampling until the determinations for folate and other chemistry.

\section{Determination of folate in red cell and its normal range}

Ascorbic acid solution was mixed with $0.5 \mathrm{ml}$ of whole blood, to which the ${ }^{125}$ I-pteroylglutamic acid tracer and milk folate binding protein had been added. Radioimmunoassay was then performed, using the CPBA method, using dextran (Clinical Assays Co. Cat. No. CA-521). The normal value for folate of 24 healthy controls ( 10 men and 14 women, mean age 27 years, range $20-38$ years) was $348 \pm 98 \mathrm{ng} / \mathrm{ml}$ (mean \pm s.d.; range $236-605 \mathrm{ng} / \mathrm{ml}$ ).

\section{Results}

The folate concentration in red cell prior to the therapy was $66 \pm 38 \mathrm{ng} / \mathrm{ml}$, being extremely low com- $\unrhd$ pared with a normal value (Figure 1). In group $A$ (Cases $1-7)(400 \mu \mathrm{g} /$ day of intravenous folic acid), red $\overrightarrow{\overline{\vec{S}}}$ cell folate levels averaged $76 \mathrm{ng} / \mathrm{ml}$ at 8 weeks from the $-\frac{7}{\sigma}$ initiation of therapy $(n=7)$ and $113 \mathrm{ng} / \mathrm{ml}$ at 16 weeks 등 $(n=3)$. In group B (Cases $8-10 ; 800 \mu \mathrm{g} /$ day), folate $\overline{\bar{\omega}}$ levels increased with time and averaged $138 \mathrm{ng} / \mathrm{ml}$ at $6 \overrightarrow{\widetilde{\phi}}$ weeks of the therapy. In a particular case (case 8 ) it $\stackrel{\circ}{\circ}$ continuously and progressively rose to a maximum of $\mathrm{c}$ $249 \mathrm{ng} / \mathrm{ml}$ at 10 weeks.

In 9 cases, TPN led to clinical remission at 8-16 weeks of the therapy; CDAI improved from 209 to $74 \vec{\omega}$ on average, and radiography or endoscopy also revealed a remarkable improvement. The remaining one case (case 10) showed a poor clinical response with TPN, and underwent an operation for stricture of the ileum after 6 weeks of therapy.

In 5 cases, mild anaemia (haemoglobin concentration: $9.5-10.3 \mathrm{~g} / 100 \mathrm{ml}$ ) was evident prior to TPN $\stackrel{\infty}{\infty}$ therapy, but improved gradually and disappeared at 8-16 weeks of the therapy. In the remaining however, haemoglobin concentration was within not $\vec{z}$ mal limits prior to and during TPN therapy. Megale blastic anaemia due to folic acid deficiency was eviden in none of the cases during this study period.

\section{Discussion}

TPN has been prescribed for patients with Crohn's disease, the objective being to improve the nutritional state and/or to induce remission of this disease in those who fail to respond to drugs. In recent years, TPN has been used as a primary therapy for Crohn's disease, ${ }^{3,5.9}$ and sustained remission has also been reported in those given long-term therapy., 10

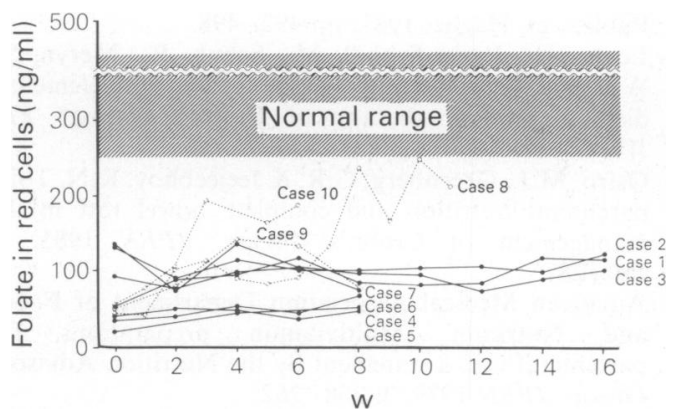

Figure 1 Serial changes in red cell concentration of folate in patients with Crohn's disease and on total parenteral nutrition. 
Folic acid deficiency can occur in patients with Crohn's disease. Hoffbrand et al. ${ }^{11}$ examined 64 patients and found very low serum levels of folate in 22 patients who required hospitalization. In 5 of 7 patients for whom assay was feasible, they also found a decrease in the red cell folate concentration. Elsborg and Larsen ${ }^{12}$ also observed decreased serum folate levels in 35 patients with Crohn's disease and attributed this to dietary insufficiency, malabsorption, and increased cell turnover.

Although the serum folate level is commonly used as a sensitive indicator for folic acid deficiency, serum folate varies with temporary changes in the intrahepatic storage or oral intake of folic acid and is also susceptible to haemolysis at the time of blood sampling. In contrast, folate concentration in red cell is relatively independent of circumstantial factors and more accurately reflects the amount of folic acid retained in the body, thus serving as a more useful index. ${ }^{13}$

In the present study, serial changes in the red cell folate were determined in patients with Crohn's disease who received folic acid of $400 \mu \mathrm{g} / \mathrm{day}$ (a dose of AMA-FDA formulation) or of $800 \mu \mathrm{g} /$ day during a relatively long-term TPN. The levels of folate were far below the normal range before TPN and remained very low during an average of 10.5 weeks of TPN with daily folic acid of $400 \mu \mathrm{g}$. In contrast, the levels in those who received a double dose of folic acid tended to increase but never reached the normal value.

The occurrence of hypervitaminosis due to an excessive administration of folic acid is rare. Hunter et $a .^{14}$ have reported that healthy subjects given intramuscular folic acid of $15,000 \mu \mathrm{g} /$ day developed mental changes, sleep disturbance, and gastrointestinal symptoms. Such symptoms, however, were not documented in our cases treated with folic acid. From these findings, folic acid of more than double the dose of the AMA-FDA formulation is considered to be necessary in patients with Crohn's disease with or without long-term TPN therapy.

\section{Acknowledgement}

We thank S. Sugiyama (Central Research Laboratory, SS Pharmaceutical Co., Ltd.) for guidance with the assay of the red cell folate concentration.

\section{References}

1. Axelsson, C. \& Jarnum, S. Assessment of the therapeutic value of an elemental diet in chronic inflammatory bowel disease. Scand J Gastroenterol 1977, 12: 89-95.

2. Driscoll, R.H. \& Rosenberg, I.H. Total parenteral nutrition in inflammatory bowel disease. Med Clin North Am 1978, 62: 185-201.

3. Greenberg, G.R. \& Jeejeebhoy, K.N. Total parenteral nutirition (TPN) in the primary management of Crohn's disease. In: Pena, A.S., Weterman, I.T., Booth, C.C. \& Strober, W. (eds) Developments in Gastroenterology: Recent Advances in Crohn's Disease. Martinus Nijhoff Publishers, Hague, 1981, pp 492-498.

4. Lochs, H., Egger-Schödl, M., Schuh, R., Meryn, S., Westphal, G. \& Pötzi, R. Is tube feeding with elemental diets a primary therapy of Crohn's disease? Klin Wochenschr 1984, 62: 821-825.

5. Ostro, M.J., Greenberg, G.R. \& Jeejeebhoy, K.N. Total parenteral nutrition and complete bowel rest in the management of Crohn's disease. JPEN 1985, 9: 280-287.

6. American Medical Association Department of Foods and Nutrition. Multivitamin preparations for partenteral use: a statement by the Nutrition Advisory Group. JPEN 1979, 3: 258-262.

7. Shils, M.E., Baker, H. \& Frank, O. Blood vitamin levels of long-term adult home total parenteral nutrition patients: the efficacy of the AMA-FDA parenteral multivitamin formulation. JPEN 1985, 9: 179-188.

8. Best, W.R., Becktel, J.M., Singleton, J.W. \& Kern, F. Development of a Crohn's disease activity index: cooperative Crohn's disease study. Gastroenterology 1976, 70: 439-444.

9. Fuchigami, T., Ohgushi, H., Imamura, K., Yao, T. Watanabe, H. \& Nakano, H. Effects of total parenteral nutrition on colonic lesions in Crohn's disease: radiographic and endoscopic study. Gastroenterol Jpn 1982, 17: 521-529.

10. Kushner, R.F., Shapir, J. \& Sitrin, M.D. Endoscopic, radiographic, and clinical response to prolonged bowel rest and home parenteral nutrition in Crohn's disease. JPEN 1986, 10: 568-573.

11. Hoffbrand, A.V., Stewart, J.S., Booth, C.C. \& Mollin, D.L. Folate deficiency in Crohn's disease: incidence, pathogenesis, and treatment. $\mathrm{Br}$ Med J 1968, 2: 71-75.

12. Elsborg, L. \& Larsen, L. Folate deficiency in chronic inflammatory bowel disease. Scand J Gastroenterol 1979 , 14: 1019-1024.

13. Chanarin, I., Smith, G.N. \& Wincour, V. Development of folate deficiency in the rat. Br J Haematol 1969, 16: 193-195.

14. Hunter, R., Barnes, J., Oakeley, H.F. \& Matthews, D.M. Toxicity of folic acid given in pharmacological doses to healthy volunteers. Lancet 1970, i: 61-63. 